\title{
INTERAKSI MANAJERIAL KEPALA SEKOLAH MELALUI STRATEGI "SIMDIK" DALAM MENATA SARANA PRASARANA SEKOLAH BERBASIS KEWIRAUSAHAAN
}

\author{
I Nyoman Suyadnya Putra \\ SD N 1 Kertha Mandala \\ Karangasem, Bali \\ e-mail: Suyadnyaputrain1@gmail.com
}

\begin{abstract}
Abstrak
Penelitian ini bertujuan untuk 1) mengetahui tindakan atau langkah yang telah diambil Kepala Sekolah dengan Strategis Simdik untuk pengadaan sarana prasarana sekolah dan mengelola Manajemen sekolah yang berbasis kewirausahaan. 2) mengetahui keterlibatan Kepala sekolah dan guru di sekolah dalam usaha pengadaan sarana prasarana di sekolah serta mengelola manajemen sekolah yang berbasis ke Wirausahaan. 3) mengetahui hasil interaksi kepala sekolah dengan guru di SD Negeri 1 Kertha Mandala berdampak positif terhadap sikap perubahan pembaharuan dari pihak guru dalam pembelajaran dengan menyediakan sarana prasarana yang memadai. Jenis penelitian ini adalah penelitian tindakan kelas (PTK). Penelitian ini dilaksanakan di SD N 1 Kertha Mandala. Metode yang digunakan dalam penelitian ini adalah metode observasi dan studi dokumen. Data dianalisis menggunakan teknik analisis statistik deskriptif. Hasil penelitian menunjukkan bahwa penerapan strategi Sistem Informasi Manajemen Pendidikan atas dasar Kewirausahaan di SD Negeri 1 Kertha Mandala adalah pertama dan utama untuk mengarahkan tugas dan tanggung jawab Kepala sekolah dalam mengelola manajemen pendidikan khususnya pengadaan sarana prasarana di sekolah dan kelas berdasarkan jiwa kewirausahaan. Memantapkan tugas pokok dan fungsi Kepala Sekolah dan guru sekaligus merupakan langkah riil yang harus didukung oleh semua belah pihak ( stakeholders ) di SD Negeri 1 Kertha Mandala. Menumbuhkan jiwa kooperatif, kreatif, inovatif dalam mengelola / manajemen pendidikan khususnya pengadaan sarana pendidikan di Sd Negeri 1 Kertha Mandala. Pengelolaan dan penataan manajemen sekolah dan kelas yang maksimal merupakan harapan peneliti untuk memunculkan era baru pendidikan menyongsong akreditasi dan sertifikasi guru yang profesional.
\end{abstract}

Kata-kata kunci : Manajerial, Sarana Prasarana, Strategi "SIMDIK".

\begin{abstract}
This study aims to 1) determine the actions or steps that have been taken by the Principal with Strategic Simdik to procure school infrastructure and manage schoolbased entrepreneurship management. 2) know the involvement of school principals and teachers in schools in the effort to procure infrastructure in schools and manage school management based on entrepreneurship. 3) knowing the results of the principal's interaction with teachers in SD Negeri 1 Kertha Mandala has a positive impact on the changing attitude of teachers on learning by providing adequate infrastructure. This type of research is classroom action research (CAR). This research was conducted at SD N 1 Kertha Mandala. The method used in this research is the method of observation and study of documents. Data were analyzed using descriptive statistical analysis techniques. The results showed that the application of the Education Management Information System strategy on the basis of Entrepreneurship in SD Negeri 1 Kertha Mandala was first and foremost to direct the duties and responsibilities of the Principal in managing education management especially the provision of infrastructure in schools and classes based on an entrepreneurial spirit. Strengthening the main tasks and functions of the School Principal and teachers at the same time is a real step that must be supported by all parties (stakeholders) in SD Negeri 1 Kertha Mandala. Fostering a cooperative, creative, innovative spirit in managing / managing education especially the
\end{abstract}


provision of educational facilities in the State Elementary School 1 Kertha Mandala. The maximum management and structuring of school and classroom management is the hope of researchers to bring up a new era of education towards professional teacher accreditation and certification.

Keywords: Managerial, Infrastructure, "SIMDIK" Strategy.

\section{Pendahuluan}

Bergulirnya reformasi yang muaranya dari hulu sampai ke hilir di negara kita (Indonesia) memunculkan paradigma baru di dunia pendidikan. Dimana layanan sebelumnya yang bersifat sentralistis menjadi desentralisasi. Kiranya reformasi dibidang pendidikan ini semstinya juga harus diimbangi dengan adanya panggilan rasa tanggung jawab terhadap tugas sebagai Kepala Sekolah plus guru dimanapun kita bertugas. Dengan memperhatikan kondisi social ekonomi masyarakat pendukung penyelenggaraan pendidikan di SD Negeri 1 Kertha Mandala, 90\% mata pencahariannya adalah bertani atau memlihara ternak yang sifatnya kecil kecilan. Minimnya lapangan kerja yang tersedia di pedesaan cukup berdampak terhadap tenaga kerja urbanisasi ke perkotaan untuk mencari kerja dalam upaya untuk memnuhi kebutuhan hidupnya. Denga adanya kondisi social ekonomi masyarakat seperti di atas cukup mempengaruhi kondisi riil di sekolah ( SD Negeri 1 Kertha Mandala ). Apalagi kalau kita telusuri lebih dalam tentang keadaan sekolah, sarana / prasarana yang ada di SD Negeri 1 Kertha Mandala, kebanyakan keberadaannya sudah using. Bantuan rehab yang diusulkan oleh pimpinan sekolah terdahulu sampai akhir tahun 2009 belum mencukupi. Hal tersebut menyebabkan kondisi gedung tidak kondusif, tembok/penyengker sekolah rusak parah, banyak perumahan guru tidak berfungsi semestinya, tidak adanya lapangan olah raga bagi siswa dan di sekolah ini belum ada unsur TIK dalam pembelajaran sehingga banyak guru gagap hasil tehnologi.

Dengan modal keberanian dan rasa tanggung jawab terhadap tugas sebagai Kepala Sekolah inti (Gugus III Kecamatan Abang ) Kami mencoba menumbuhkan jiwa kewirausahaan untuk mengolah dapur sendiri dengan mengadakan rapat rapat koordinasi dengan stakeholders disekolah. Membuat kata sepakat untuk mengadakan trobosan dengan membuat usulan kepada pemangku kepentingan di bidangnya.

Sesuai dengan visi, misi sekolah, maka minimal kepala sekolah bersama guru harus siap menerima "perubahan", perubahan kearah maju khususnya bagaimana kita mampu mengadakan, mengelola / menata sarana prasarana sekolah sehingga pembelajaran berjalan aman, nyaman dan terkendali. Mau dan mampu memunculkan siswa terampil, mandiri serta mempunyai kemampuan dasar yang memadai sesuai dengan karakteristik pendidikan di satuan pendidikan.

Walaupun seperangkat peraturan, tata tertib telah matang, tetapi realita di lapangan khususnya di SD Negeri 1 Kertha Mandala, masih perlu ditata bersama-sama. Mengingat kepedulian masyarakat sebagai pendukung pendidikan sebatas wacana, ditambah perekonomiannya rendah, yang menyebabkan inkamperkapita rendah ditambah sikap guru hanya menunggu komando saja, kurang lengkapnya buku-buku, tidak adanya klasifikasi administrasi sekolah dan kelas, tidak ada inisiatif menggunakan sumber daya yang ada sesuai dengan prinsip administrasi yaitu melayani. Kurangnya perangkat pembelajaran di kelas disebabkan oleh adanya keengganan dari guru untuk mengarsip/ memfortopolio kelas sehingga suasana kelas menjadi kering pada hal kelas semestinya menjadi sumber informasi bagi siswa dalam pembelajaran.

Yang melatar belakangi adanya pemilihan strategi SIMDIK, karena selama pengamatan peneliti mulai bertugas di sekolah ini melihat kondisi sarana prasarana sekolah tidak memadai, walaupun ada banyak yang sudah usang / rusak. Secara rinci alasan pemilihan strategi simdik adalah: 1) Kondisi sarana prasarana khususnya (gedung, perumahan, tembok penyengker sekolah sudah tidak layak pakai. Hal ini tentu sangat berdampak dukungan dan kelancaran 
proses pembelajaran di SD Negeri 1 Kertha Mandala ini. 2) Karena SD 1 Kertha Mandala ini termasuk SD inti Gugus II Kecamatan Abang dan memeiliki ruang Pusat Kegiatan Guru (PKG) yang dibangun pada jaman proyek PEQIP (Premery Education Quality Imfroment Project) juga sudah rusak (lantai, plapon, atap termasuk barang dan peralatan lainya). 3) Sebagai sekolah inti Gugus III Kecamatan Abang dari tahun 2009 sistem pembelajaran belum tersentuh oleh media pembelajaran yang berbasiskan E-Learning atau TIK sebagai basis pembelajaran yang bernuansa inovatif. 4) Manajemen Berbasisi Sekolah (MBS) membenarkan seorang Kepala Sekolah mengembangkan jiwa kewirausahaan untuk pengadaan sarana dan prasarana pembelajaran disekolah. Mencarikan informasi yang sebanyak banyaknya melalui media cetak maupun elektronik, bila perlu mencari para donator, alumnus yang telah berhasil dalam pekerjaan. Mengembangkan jiwa kepekaan terhadap dalam membangun generasi muda yang mencerminkan jati diri karakter bangsa Indonesia yang berbudaya Adiluhung itu.

\section{Metode}

Jenis penelitian ini adalah Penelitian Tindakan Kelas (PTK). Penelitian ini dilaksanakan di SD N 1 Kertha Mandala. Metode yang digunakan dalam penelitian ini adalah metode observasi dan studi dokumen.

\section{A. Observasi Awal}

Sesuai pengalaman lapangan kepala sekolah mengadakan koordinasi dengan stakeholders di sekolah untuk mengadakan observasi awal, tujuannya untuk menganalisa masalah-masalah yang ada di sekolah yang berkaitan dengan manajemen sekolah dan kelas. Pengamatan pendahuluan ini akan merupakan obyek penelitian, termasuk situasi kelasnyadengan sarana prasarananya.

Dari hasil observasi lapangan secara langsung terhadap kondisi sekolah dan kelas serta kesiapan guru dalam mengelola sarana sekolah secara garis besar dapat dicatat sebagai berikut:

Kearsipan tentang inventaris barang ( sarana) sekolah perlu diklasifikasi.

1. Adanya kebiasaan lama di sekolah sarana yang ada tidak dimanfaatkan sebagaimana mestinya.

2. Kurang bermaknanya praktek pembelajaran karena guru tidak mengambil langkah untuk mengalihkan suasana kelas ke suasana belajar dengan sarana pembelajaran yang ada.

3. Umpan balik berupa pertanyaan-pertanyaan, guru selalu mengarahkan pada siswa yang aktif saja.

4 Belum ada pembelajaran yang menerapkan E. Learning di kelas

5 Hancurnya pagar sekolah yang perlu mendapat perhatian dari sekolah.

6. Gedung PKG (Pusat Kegiatan Guru) sebagai SD inti rusak berat.

7. Kurang pedulinya guru terhadap kelas lain karena gurunya tidak masuk/ijin.

8. Guru jarang/belum pernah mengangkat masalah yang diamati di kelas untuk dipecahkan secara bersama antara kepala sekolah bersama guru lain, (maju bersama). Atau membawa masalah pembelajaran (mengelola kelas) ke ruang dapur KKG.

\section{B. Diskusi Awal}

Berdasarkan hasil observasi awal kepala sekolah (peneliti) terhadap pengelolaan manajemen sarana prasarana sekolah dan kelas (pembelajaran) ternyata masih banyak penyimpangan seperti uraian di atas. Sehingga hal tersebut dianggap oleh kepala sekolah suatu masalah yang harus dipecahkan bersama, diskusikan bersama untuk menentukan arah dan tujuannya. Lebih-lebih guru sekarang secara proaktif dituntut untuk menunjukkan profesionalisme guru. Dalam hal ini komunikasi sinergis (kepala sekolah-guru) di sekolah. Melangkah secara bersama-sama merumuskan masalah untuk dicarikan alternatif tindakan, Hasilnya kemudian dijadikan Rekomendasi untuk mengadakan usulan keinstansi terkait. 
Beberapa alternatif tindakan yang dikerjakan kepala sekolah dalam pengadaan sarana prasarana/perehaban sekolah dan kelas yang dapat direkomendasikan antara lain :

1. Mengklasifikasi keberadaan sarana yang ada seoptimal mungkin dan menerapkan strategi pembelajaran yang PAIKEM untuk mengundang partisipasi aktif siswa dalam belajar.

2. Membuat,merencanakan dan mengusulkan keberbagai instansi terkait untuk melengkapi sarana prasarana di SD Negeri 1 Kertha Mandala.

3. Guru perlu menata sarana/prasarana, melengkapi administrasi dan kearsipan kelas berupa portofolio kelas, sehingga guru memiliki dokumen resmi kelas sebagai bahan pertimbangan dan pertanggungjawaban proses pendidikan pada masyarakat pendukung SD Negeri 1 Kertha Mandala. Hal ini sekaligus bukti realisasi "Sistem informasi manajemen pendidikan atas dasar Kewirausahaan kepala sekolah bersama guru komite di SD Negeri 1 Kertha Mandala.

\section{Metode Studi Dokumen}

Mekanisme pengumpulan data yang dilakukan dengan cara mencari sejumlah dokumen dan informasi yang kontinyu dan cermat tentang sarana yang ada di SD Negeri 1 Kertha Mandala. Kelengkapan dokumen sarana ini diupayakan untuk diklasifikasi baik berupa tulisan maupun berupa/barang. Selanjutnya dianalisa untuk mencari dan menutupi kekurangannya sehingga pada saat dipergunakan lengkap adanya. Dengan studi dokumen kita akan temui kearsipan setiap periode pemimpin yang pernah menjabat di SD Negeri 1 Kertha Mandala ini. Hal ini juga merupakan refrensi pembanding bagi kepala sekolah yang menjabat sekarang untuk diadakan perubahan kearah yang lebih baik dan sesuai dengan keperluan pelayanan pendidikan sekarang. Untuk itu pengarsipan berupa portofolio semua dokumen sekolah amatlah penting artinya bagi peneliti, sebab dengan studi dokumen kita dapat gambaran jelas tentang perkembangan dan langkah apa yang pernah direalisasikan oleh seorang kepala sekolah yang pernah menjabat pada satuan pendidikan ( SD Negeri 1 Kertha Mandala).

\section{Hasil dan Pembahasan}

Sesuai strategi yang diterapkan kepala sekolah dalam menghadapi situasi / keadaan sekolah (SDN 1 Kertha Mandala) seperti diatas sudah menampakkan hasil seperti harapan bersama. Dari kurun waktu yang relatip singkat yaitu dari tahun 2016 sampai sekarang kepala sekolah terus megadakan koordinasi intensip. Dari perencanaan, koordinasi, mencarikan informasi yang sesuai dengan pengadaan sarana di sekolah, mengusulkan memakai proposal sampai ada hasil di sekolah dampak dari hasil penerpan strategi "Simdik". Sebagai bukti atas dampak yang ditmbulkan dengan diterapkannya Strategi "Sistem Informasi Manajemen Pendidikan atas dasar Kewirausahaan", di SD Negeri 1 Kertha Mandala cukup menjawab harapan warga sekolah termasuk masyarakat pendukung sekolah. Hal tersebut dibuktikannya melaui sosialisasi hasil dari berbagai usulan Kepala Sekolah kepada warga sekolah dan masyarakat yang ditokohkan. Secara rinci dampak tersebut adalah :

\section{A. Meningkatkan Pengelolaan Pembelajaran Lebih Efektif}

Berkat aktualisasi sistem informasi manajemen dan jiwa kewirausahaan Kepala Sekolah dalam pengadaan sarana prasarana di sekolah, cukup berpengaruh positip terhadap kinerja para guru dalam melaksanakan tugas sebagai guru. Mau membelajarkan diri walaupun sudah usia dan berpartisipasi aktip dalam menggeliatkan program sekolah yang inovatip itu. Guru guru mau melengkapi dan memvariasikan model pembelajaran de kelas dengan mamasukkan unsureunsur TIK, sehingga siswa menyenangi pembelajaran. Mencarikan informasi pendidikan melalui media internet dan meragamkan strategi /tehnik pembelajaran sehingga suasana kelas menjadi tidak membosankan siswa. Mengoptimalisasi penggunaan sumber sumber belajar yang ada disekolah dan lingkungannya sebagai langkah antisipasi menghilangkan kejenuhan siswa di kelas. 


\section{B. Menumbuhkan Paradigma Baru Masyarakat di Bidang Pendidikan}

Sebagai konsekuensi logis terhadap sosialisasi Strategi sistem informasi manajemen pendidikan atas dasar kewirausahaan di SD Negeri 1 Kertha Mandala, cukup mampu menumbuhkan pola pemikiran baru di masyarakat. Paradigma baru masyarakat dibidang poendidikan tersebut adalah :

a. Adanya kerja sama yang baik dan harmonis di sekolah dengan masyarakat pendukung sekolah serta ikut serta secara aktip menjaga keamanan sekolah

b. Orang tua siswa cukup perhatian terhadap kepntingan sekolah khususnya yang masih berhubungan dengan pelayanan pendidikan di sekolah. Masyarakat mulai menyadari bahwa pendidikan itu bukan tanggungjawab sekolah saja malainkan menjadi tanggungjawab kita bersama.

c. Dengan dilihatnya bukti berupa hasil kewirausahaan di sekolah, maka masyarakat mulai menginformasikan bahwa di Sd Negeri 1 Kertha Mandala itu sudah ada sarana dan prasaran pendidikan yang cukup untuk mengembangkan kompetensi siswa dimasa masa mendatang.

d. Lengkapnya sarana prasarana berkreativitas di sekolah sekaligus akan mengundang kehadiran siswa ke sekolah termasuk pendaftaran siswa baru. Menagkal / menepis munculnya angka doup out yang memungkinkan siswa menjadi buta huruf

\section{Beragamnya Prestasi Sekolah}

Penyampaian informasi yang jelas tepat dan cepat ke sekolah akan berdampak pada kinerja Kepala sekolah SD Negeri 1 Kertha Mandala. Melalui sistim informasi manajemen pendidikan atas dasar kewirausahaan ini jelas berpengaruh terhadap prestasi siswa bai akademik maupun non akademik. Sekolah bersama warganya merasa tertangtang untuk ber aktivitas maupun berkreativitas dalam member pelayanan pendidikan terbaik di sekolah.

\section{Membudayakan Jiwa Kewirausahan di Bidang Pendidikan}

\section{Internal Sekolah :}

a. Dikalangan Siswa Kegiatan Kewirausahaan antara lain

Dengan jumlah siswa 145 siswa hamper seluruhnya menerpakan pola hidup sederhana serta hemat di sekolah. Kewirausahaan ini tercermin dari semakin meratanya siswa gemar menabung di sekolah. Langkah ini ditempuh sebagai langkah antisipasi kegiatan sekolah yang memerlukan dana dikemudian hari. Mengembangkan jiwa kewiraan melalui kegiatan sekolah/Ekstrakurikuler (Pramuka) sebagai wadah resmi pembinaan karakter siswa. Mendidik jiwa anak menjadi berikari (Berdiri di atas kaki sendiri) untuk mengurangi ketergantungan pada orang lain. Menumbuhkan jiwa pantang menyerah pada siswa dalam kegiatan akademik maupun non akademik 9 mencapi nilai terbaik, ketuntasan dalam mengikuti semester, ujian termasuk formatip. Menampilkan diri sebagai siswa yang mandiri dalam meraih prestasi dibidang Olah Raga dan berkesenian atau lomba yang lainnya.

b. Dikalangan Guru Jiwa Kewirausahaan

Membelajarkan diri bagaimana cara menguasai tehnologi informasi dan komunikasi sebagai langkah onovatip sebagai guru. Menguasai cara cara menumbuhkan jiwa kewirausahaan dalam menata apik sarana dan proses pembelajaran di sekolah sehingga pigur guru tidak ditinggalkan oleh siswanya. Mengoptimalisasi waktu yang ada untuk mengakses sumber sumber pembelajaran lewat media cetak maupun media elektronik yang ada di sekolah. Menjalin hubungan suka duka antar warga sekolah (Kepala sekolah Guru - Pegawai - Siswa) di sekolah (human retions) sebagai implementasi jiwa kemandiri warga sekolah (SD Negeri 1 Kertha Mandala). 
Eksternal Sekolah :

a. Menteladani Jiwa Kewirausahaan

Eksistensi tanggungjawab dan model yang ditempuh dalam pengembangan dan pengadaan sarana prasarana di SD Negeri 1 Kertha Mandala adalah strategi SIMPAK. Berpedoman kepada informasi manajemen yang valid dan dapat dipercaya untuk menumbuh kembangkan jiwa kewirausahaan sebagai Kepala Sekolah. Apapun hasil trobosan Kepala Sekolah bersama warga sekolah dimohonkan untuk dipublikasikan / diumumkan atau dipublikasikan sebagai jembatan dalam menteladani jiwa kewirausahan Kepala sekolah kepada sekolah imbas. Pengimbasan ini akan berpengaruh besar terhadap kenerja Kepala Sekolah lain yang mampu dan mau mengelola sarana prasarana sekolahnya sesuai dengan anilasa kebutuhan sekolah bersangkutan.

b. Pengaruh Kewirausahaan pada Sekolah Imbas

Dengan adanya hasil yang ada di Sd Negeri 1 Kertha Mandala sekalugus sekaligus sebagai SD inti, jelas berpengaruh pada SD imbas yang diwilayahi oleh SD Negeri 1 Kertha Mandala. Melalui dapurnya Pusat Kegiatan Guru (PKG) yang ada di gugus inti Kepala sekolah lewat Kelompok Kerja Kepala Sekolah (KKKS) akan tetap mengadakan koordinasi sinergis mengenai langkah langkah apa yang harus diambil untuk mengadakan sarana prasarana disekolah. Kepala Sekolah inti berusaha memberikan informasi yang sejelas jelasnya terhadap kebutuhan sekolah imbas. Dengan konsekuensi sebagai Kepala Sekolah inti wajib menyampaikan formasi dan informasi kepada Kepala Sekolah imbas langkah langkah yang harus ditempuh untuk memecahkan masalah sarana yang dihadapi disekolahnya. Dengan berbasis Kelompok Kerja Guru (KKG) yang dilaksanakan di SD 1 Kertha Mandala(SD inti), Kepala Sekolah SD inti wajib juga menuntun serta menginformasikan sistem informasi manajemen pendidikan yang berbasis kewirausahaan. Mencari dan menemui sistem pembelajaran di sekolah yang berbasis TIK.

\section{E. Kendala dalam Melaksanakan Strategi "Simdik"}

Dalam penerapan strategi sitem informasi pendidikan atas dasar kewirausahaan di sekolah dasar ada beberapa hambatan atau kendala yang harus dianalisa untuk dicarikan jalan keluarnya. Diantara kendala yang ada dapat dirinci seperti berikut ini : 1) Ada guru kita belum bisa / biasa mengoperasikan computer di sekolah yang disebabkan oleh adanya rasa enggan karena faktor usia dan masa kerja yang berpengaruh pada etos kerja seorang guru. 2) Sarana bantuan tidak / belum berfungsi optimal karena kesempatan dan waktu luang guru di sekolah sangat terbatas untuk membelajarkan diri khususnya dalm penguasaan pembelajaran berbasis TIK. 3) Terbatasnya tenaga kependidikan yang mampu mengoperasikan media pembelajaran yang berbasis TIK dan tidak meratanya penempatan tenaga TU di sekolah dasar.

\section{F. Faktor Pendukung Pelaksanaan Strategi "Simdik"}

Faktor pendukung pertama dan utama pelaksanaan strategi sistem informasi manajemen pendidikan atas dasar kewirausahaan di Sd Negeri 1 Kertha Mandala adalah :1) Suasana kondusip disekolah yang memungkinkan Kepala Sekolah mengadakan koordinasi sinergis di sekolah untuk merekomendasi perencanaan yang dikeluarkan Kepala Sekolah. 2) Motivasi yang secara terus menerus dari pengurus komite sekolah terhadap Kepala Sekolah untuk mau mengadakan trobosan baru di SD Negeri 1 Kertha Mandala dalam rangka melengkapi sarana prasarana pembelajaran di sekolah. 3) Pembinaan secara organisatoris dari instansi terkait tentang tugas tugas serta kompetensi yang harus dikembangkan oleh seorang Kepala sekolah. Sehingga sekolah yang dipimpinnya mendapat apresiai positip dari masyarakat pendukungnya. 4) Merealisasikan Visi dan Misi sekolah yang menjadi panduan sekolah dalam mewujudkan program sekolah, serta pengembangan kompetensi guru guru yang sudah mendapat sertifikat guru bersertifikasi 


\section{G. Alternatif Pengembangan Strategi "Simdik"}

Berdasarkan kebutuhan sekolah yang dianalisis setiap tahun tentu ada saja kekurangan kekurangan yang dipenuhi oleh sekolah. Walupun dalam pengadaan sarana prasarana di Sd Negeri 1 Kertha Mandala cukup memadai, tetapi masih banyak yang perlu yang harus dikembangkan. Sebab peneliti menyadari pelayanan pendidikan itu bersifat berkesinambungan / terus menerus untuk menuju kearah yang lebih baik. Merancang model model pendidikan dan latihan (Diklat) yang lebih inovasi dalam membangkitkan kinerja guru. Apalagi diberlakukannya Permen PAN reformasi birokrasi nomor 16 tahun 2009 tentang "Penilaian jabatan guru dengan Angka Kreditnya, Maka Sd Negeri 1 Kertha Mandala menyambut dengan diadakannya Diklat. PK. Guru. Dimana Anggaran Diklat PK Guru ini berasal dari hasil kompetisi Blockgrand diklat PK guru yang dilaksanakan oleh lembaga Penjaminan Mutu Pendidikan (LPMP) Bali tahun 2011. Memotivasi guru guru yang ada di Sd Negeri 1 Kertha Mandala mau melanjutkan kwalifikasi pendidikan minimal S, 1 bahkan melanjutkan perkuliahan ke program pascasarjana ke 2. Mencari informasi dengan sumber yang jelas untuk ikut kegiatan lomba akademik atau non akademik.

Mensosialisasikan dan menyuarakan suatu budaya sekolah yaitu "Tiada Hari Tanpa Berjiwa Kewirausahaan". Serta menjalin kerja sama harmonis kepada para pemangku kepentingan dan stakeholders di sekolah yang memudahkan tercapainya tujuan program sekolah.

\section{Simpulan dan Saran}

Dari hasil penelitian di atas, dapat dibuatkan simpulan sebagai berikut: 1) Penerapan strategi Sistem Informasi Manajemen Pendidikan atas dasar Kewirausahaan di Sd Negeri 1 Kertha Mandala adalah pertama dan utama untuk mengarahkan tugas dan tanggung jawab Kepala sekolah dalam mengelola manajemen pendidikan khususnya pengadaan sarana prasarana di sekolah dan kelas berdasarkan jiwa kewirausahaan. 2) Memantapkan tugas pokok dan fungsi Kepala Sekolah dan guru sekaligus merupakan langkah riil yang harus didukung oleh semua belah pihak (stakeholders) di SD Negeri 1 Kertha Mandala. Menumbuhkan jiwa kooperatif, kreatif, inovatif dalam mengelola / manajemen pendidikan khususnya pengadaan sarana pendidikan di Sd Negeri 1 Kertha Mandala. 3) Pengelolaan dan penataan manajemen sekolah dan kelas yang maksimal merupakan harapan peneliti untuk memunculkan era baru pendidikan menyongsong akreditasi dan sertifikasi guru yang profesional.

Adapun Saran-saran dalam penelitian ini adalah 1) Adakan pembinaan secara terus untuk mencari informasi terbaik sebagai menunjang tugas-tugas pokoknya Kepala sekolah. Hal ini untuk menghindari persepsi miring tentang kepala sekolah yang enggan berbuat di sekolah. 2) Musyawarah untuk mencapai mufakat adalah langkah kongkrit Kepala sekolah terhadap stakeholders untuk mengemban tugas mulia (memimpin,mendidik, membimbing, dan bekerja) di sekolah dalam mengelola sarana sekolah untuk menciptakan suasana aman, nyaman di sekolah. 3) Pelayan pendidikan hendaknya mampu dan mau menjadi diri sebagai orang tua kedua di sekolah, sehingga apapun langkah Kepala sekolah bersama guru dalam mengelola sarana dan kelasnya, tetap merupakan suritauladan di hati.

\section{Daftar Pustaka}

Arikunto Suharsini. 1994. Pengelolaan Kelas dan Siswa Sebuah Pendekatan Evaluasi. CV. Rajawali: Jakarta

Departemen Pendidikan dan kebudayaan Republik Indonesia,1998, Kamus Dasar Bahasa Indonesia. Jakarta, Forum Balai Pusaka. 
Departemen Pendidikan Nasional, 2013, Undang Undang Sistim Pendidikan Nasional, Jakarta.

Dirjen. Diknas 2011, Pedoman Pemilihan Kepala Sekolah Berprestasi, Jakarta, Direktorat Pembinaan Pendidik dan Tenaga Kependidikan Dasar 2012.

Gina, I Wayan. 1970. Rincian Tugas Guru SD, Departemen Pendidikan dan Kebudayaan Kabupaten Karangasem.

Gunawan, K. Abadi. 2003. Kamus Praktis Bahasa Indonesia. CV. Kartika Surabaya

Joko Anggodo, 2007, Metode Penelitian, Jakarta: universitas Terbuka.

Muhyasa, E, 2002, Manajemen Berbasisi Sekolah, Bandung, PT. Remaja Rosdkarya.

Poerwadarminta, 2007, Kamus Besar Bahasa Indonesia.

Pryono, Joko. 2006. Pelangi Pendidikan. Direktorat Pembinaan Sekolah Menengah, Jakarta.

Soesarsono, Wijandi, 1987, Pengatur Kewirausahaan,, Bandung,: Sinar terbuka.

Suprayeti. 2004. Interaksi Belajar Mengajar. Direktorat Jenderal Pendidikan Dasar dan Menengah Direktorat Tenaga Kependidikan.

Umaedi, 2007, Manajemen Berbasis Sekolah, Jakarta, Universitas Terbuka.

Wardani IGK, 2002, Tehnik Menulis Karya IImiah, Jakarta, Universitas terbuka.

Wibawa, H. Basuki. 2004. Penelitian Tindakan Kelas. Direktorat Jenderal Pendidikan Dasar dan Menengah Direktorat Tenaga Kependidikan. 